\title{
Assessment of carbon allocation and biomass production in a natural stand of the salt marsh plant Spartina anglica using ${ }^{13} \mathrm{C}$
}

\author{
M. A. Hemminga*, A. H. L. Huiskes, M. Steegstra, J. van Soelen
}

Netherlands Institute of Ecology, Centre for Estuarine and Coastal Ecology, Vierstraat 28, 4401 EA Yerseke, The Netherlands

\begin{abstract}
The proportional allocation of photosynthetically fixed carbon to the root and shoot system of salt marsh plants is an important element in the carbon cycle of tidal salt marshes. The commonly applied field methods giving insight on this point are based on successive harvesting of biomass. These methods, however, lack accuracy and do not yield reliable data over short time intervals. In the present study, the stable carbon isotope ${ }^{13} \mathrm{C}$ was used as a tracer of carbon flow in Spartina anglica. Shoot clusters of this halophyte were incubated with ${ }^{13} \mathrm{CO}_{2}$ (ca 1 h) in a salt marsh in the SW Netherlands. Four days after the incubations, shoots and roots/rhizomes were sampled to determine enrichment with the heavy isotope. Although $S$. anglica is a clonal plant, only a minor part of the excess ${ }^{13} \mathrm{C}$ incorporated in plant tissues due to the incubation procedure was found outside the incubation plots. The data revealed the dynamic nature of carbon allocation in $S$. anghca, leading to seasonal changes in the ratio of carbon allocated to above-ground versus below-ground tissues. The ratio was highest in August (6.19) and lowest in September (1.60), but more carbon was always invested in above-ground plant parts than in below-ground plant parts. These findings strongly suggest that, on an annual basis, above-ground biomass production outweighs below-ground biomass production in this $S$. anglica population. Root/rhizome production over short-term periods ( 10 to $12 \mathrm{~d}$ ) was calculated by combining the data on the ratios of ${ }^{13} \mathrm{C}$ allocation with measurements of above-ground biomass increments over these periods. On an annual basis, above-ground and below-ground biomass production was estimated to be 1130 and $556 \mathrm{~g}$ dry $w \mathrm{t} \mathrm{m}^{-2}$, respectively. A survey of the literature shows that the ratio of shoot to root/rhizome production of Spartina spp. vegetation is highly variable, ranging from a clear dominance of shoot production (as is suggested by our data) to the completely opposite situation with root/rhizome production amply exceeding shoot production. This may imply considerable differences in the functioning of Spartina-dominated marsh systems, e.g. with respect to the dominance of aerobic or anaerobic mineralization processes and to mineralization-linked cycling of sulphur and nitrogen.
\end{abstract}

KEY WORDS: Spartina anglica Salt marshes - Carbon allocation - Production - Stable carbon isotopes

\section{INTRODUCTION}

Tidal salt marshes are highly productive coastal fringe ecosystems. The major contributors to this productivity are the vascular plants, although benthic and planktonic algae can also make a significant contribution (Long \& Mason 1983, Adam 1990, Sullivan \& Moncreiff 1990, Bakker et al. 1993). The above-ground productivity of salt marsh angiosperms has been extensively documented, particularly that of species

·E-mail: hemminga@nioo.n] belonging to the genus Spartina, which often dominate large parts of the marshes. The practical difficulties involved in determining root and rhizome production is an obvious reason for the relative scarcity of data on this point. However, for a proper understanding and quantification of carbon and nutrient cycles in the salt marsh, the below-ground plant system must be considered together with the above-ground parts for at least 2 important reasons. In the first place, a number of studies on Spartina spp. indicate that the root/rhizome system may surpass the aerial plant parts in terms of both biomass and productivity (e.g. Roman \& Daiber 1984, Schubauer \& Hopkinson 1984, Dame \& Kenny 
1986, Groenendijk \& Vink-Lievaart 1987, da Cunha Lana et al. 1991). Hence, next to aerial productivity, the formation of below-ground biomass is an important term in the carbon cycle of salt marshes dominated by Spartina spp. Secondly, in comparison with other ecosystems, salt marsh sediments have some of the highest rates of heterotrophic bacterial activity, and it is known that many microbial processes in the sediment are closely linked to the functioning of the marsh plants (Howarth 1993). The roots most likely play a crucial role in influencing these processes by providing the microbial community with both particulate and dissolved organic matter (Mendelssohn et al. 1981), and by leakage of oxygen from air spaces in the tissues to the rhizosphere (Reddy et al. 1989, Lindau \& Delaune 1991).

Both the current assessments of sediment carbon input associated with root growth and the interpretation of spatial and temporal patterns in sediment microbial activities (such as sulfate reduction) suffer from a lack of accurate data on the dynamics of carbon allocation to the root/rhizome compartment (Morris et al. 1984, King 1988, Hines et al. 1989). Nearly all studies on the dynamics of Spartina root/rhizome production are based on comparisons of biomass present in soil samples collected at successive time intervals. The notoriously large variability between replicate samples connected with such harvest methods precludes meaningful conclusions for short time intervals. Moreover, root/rhizome production cannot be directly related to investments in above-ground biomass.

The present study describes and applies a field method yielding quantitative information on the proportional allocation of photosynthetically assimilated carbon to the root and shoot system of Spartina anglica. The stable carbon isotope ${ }^{13} \mathrm{C}$ was applied as a tracer of carbon flow in the plants. Earlier studies have shown the potential usefulness of this isotope for the assessment of carbon allocation in plants (Mordacq et al. 1986, Svejcar et al. 1990). The resulting data were used to estimate below-ground biomass production over short time intervals. The data reveal the dynamic nature of carbon allocation in $S$. anglica, leading to seasonal changes in the ratio of carbon allocated to above-ground versus below-ground tissues. In contrast to the majority of available data on below-ground biomass production of Spartina spp., our data indicate that above-ground biomass production amply exceeds below-ground production.

\section{MATERIALS AND METHODS}

Study site. The study was carried out in the salt marsh near Ritthem ( $\left.51^{\circ} 27^{\prime} \mathrm{N}, 3^{\circ} 40^{\prime} \mathrm{E}\right)$, near the mouth of the Westerschelde estuary (SW Netherlands). The mean tidal range in this part of the estuary is ca $3.8 \mathrm{~m}$. The angiosperm vegetation in the lower zone of the Ritthem salt marsh is formed nearly exclusively by monospecific stands of Spartina anglica. These stands are inundated each flood tide. A representative $5 \times$ $15 \mathrm{~m}$ area of $S$. anglica vegetation was selected for the present study. Sampling and in situ experimental procedures were repeated 4 times during the growing season: in May, June/July, August and September 1994, respectively.

Seasonal changes in biomass and carbon content. The biomass of above-ground and below-ground Spartina anglica during the growing season was determined by harvesting the shoots from 3 plots of $25 \times$ $25 \mathrm{~cm}$, and by collecting root/rhizome material to a depth of 45 to $50 \mathrm{~cm}$, with a $7 \mathrm{~cm}$ inner diameter plunger-type coring device (4 replicates). The aboveground material was washed in tap water to remove adhering silt. Prior to drying $\left(72 \mathrm{~h}, 70^{\circ} \mathrm{C}\right)$, the length of the harvested stems and leaves was measured for determination of mathematical relations between lengths and dry weights (see below). Roots and rhizomes were separated from soil particles by rinsing the material over a $1 \mathrm{~mm}$ mesh sieve. Dead root/rhizome material was carefully removed from the samples (roots were considered to be living when they were white). The remaining living material was dried $\left(72 \mathrm{~h}, 70^{\circ} \mathrm{C}\right)$ and weighed. Carbon content of the samples was determined with a Carlo Erba NA1500 CN analyzer.

Carbon allocation. To determine carbon allocation to the shoots and the roots/rhizomes, Spartina anglica shoots were incubated with ${ }^{13} \mathrm{CO}_{2}$. For this purpose, a transparent perspex cylinder (height $50 \mathrm{~cm}$; diameter $14 \mathrm{~cm}$ ) was positioned over the canopy. The top of the cylinder was closed with a perspex lid. The bottom of the cylinder was sunk $1 \mathrm{~cm}$ into the soil to stabilize the cylinder and to prevent leakage of gases out of the resulting incubation chamber. A temperature sensor was positioned in the cylinder at half height. To main tain a well-mixed atmosphere in the cylinder, and to prevent unwanted deviations of the temperature in the cylinder relative to ambient levels, a cooling unit was connected to the cylinder, comprising a small fan and a peltier element. Butyl rubber tubes were used for connections. The capacity of the fan was $11 \mathrm{~min}^{-1}$. The cooling unit kept the temperature in the cylinder within $5^{\circ} \mathrm{C}$ above ambient air temperature. The decrease in carbon dioxide in the cylinder was monitored with an LCA2 Infra Red Gas Analysis (IRGA) system. (ADC, Hoddesdon, UK) used in a closed system configuration. Air samples were taken at the air outlet of the cylinder and pumped through the IRGA, using both the analysis air inlet and the reference air inlet and pumped back into the cylinder again by the inter- 
nal pump. The flow through the IRGA was $150 \mathrm{ml}$ $\mathrm{min}^{-1}$. Every $2 \mathrm{~s}$ the measuring cell of the IRGA alternates between measurement of untreated air from the cylinder and air from the cylinder that has first had its carbon dioxide removed by passage through soda lime. This means that $50 \%$ of the total volume of carbon dioxide passing through the IRGA is absorbed by the soda lime. The IRGA used in the experiments was fitted with a standard narrow band optical absorption filter. The sensitivity of this filter for measurement of ${ }^{12} \mathrm{C}$ relative to ${ }^{13} \mathrm{C}$ was 1:0.11.

The incubations with ${ }^{13} \mathrm{CO}_{2}$ started by slowly injecting $10 \mathrm{ml} 0.1 \mathrm{~N} \mathrm{HCl}$ through an injection port in the incubation chamber into a small vial containing ${ }^{13} \mathrm{C}$-sodium carbonate $\left(99.1\right.$ atom $\%{ }^{13} \mathrm{C}$; Isotec Inc., Miamisburg, $\mathrm{OH}$, USA). The resulting evolution of $\mathrm{CO}_{2}$ and subsequent uptake by the plants was monitored with the IRGA. Approximately $10 \mathrm{~min}$ after the first pulse of ${ }^{13} \mathrm{CO}_{2}$, a second, equally large pulse was given by injecting acid into a second vial with ${ }^{13} \mathrm{C}$-sodium carbonate. In the first incubation experiments (May 10), a total quantity of $120 \mathrm{mg} \mathrm{Na}_{2} \mathrm{CO}_{3}$ per plot was used (equivalent to $14.6 \mathrm{mg}^{13} \mathrm{C}$ ). In the subsequent incubation experiments on June 23. August 15 and September 12 , 197 or $395 \mathrm{mg}$ quantities of $\mathrm{Na}_{2} \mathrm{CO}_{3}$ were used per plot (equivalent to 24 and $48 \mathrm{mg}{ }^{13} \mathrm{C}$, respectively). On each date, 3 replicate plots were successively incubated during the same ebb tide. This restricted the time available for each incubation to ca $60 \mathrm{~min}$. However, at the end of each incubation, $\mathrm{CO}_{2}$ concentrations had returned to levels below ambient atmospheric levels. All incubations were carried out between 09:00 and 16:00 h, i.e. under full daylight conditions.

After the incubations, the plants were left under normal growing conditions for $4 \mathrm{~d}$ to allow for complete translocation of carbon from the exposed leaves to the other plant parts (cf. McCree 1974, Ryle et al. 1976). After this period, the above-ground and below-ground biomass in the central circular area (diameter $7 \mathrm{~cm}$ ) of the incubation plots was harvested. The below-ground material was collected with the sediment corer to a depth of 45 to $50 \mathrm{~cm}$. Stable carbon isotope analyses were carried out on these samples. The remaining parts of the shoots in the incubation plots were also harvested, to obtain data on total biomass in the plots.

Spartina anglica is a clonal plant with rhizomes spreading horizontally. To determine whether ${ }^{13} \mathrm{C}$ was exported via the rhizome system out of the incubation area, above-ground and below-ground biomass was collected from circular areas (diameter $7 \mathrm{~cm}$ ) outside each incubation plot. The position of these areas around the incubation plot was random, except with respect to their distance: the centres of the areas were $10.5,17.5,24.5$, and $31.5 \mathrm{~cm}$ away from the centre of the incubation plot.
Rinsing and drying of all Spartina anglica samples followed the procedures described above. The ${ }^{13} \mathrm{C}$ content and the total carbon content of the samples were determined, respectively, with a Europe Scientific Tracermass mass spectrometer and the Carlo Erba NA1500 CN analyzer mentioned earlier.

Results of the carbon isotope analyses are reported in the $\delta$ notation, with PDB limestone as the standard. Reproducibility was better than $0.4 \%$. In order to calculate the amount of ${ }^{13} \mathrm{C}$ in the plant tissues, the absolute stable carbon isotope ratios $(R)$ were converted to fractional abundances $(F)$ according to the formula (see e.g. Boutton 1991):

$$
F=\frac{{ }^{13} \mathrm{C}}{{ }^{13} \mathrm{C}+{ }^{12} \mathrm{C}}=\frac{R}{R+1}
$$

Subsequently, the fractional abundance of ${ }^{13} \mathrm{C}$ in the sample was multiplied with the carbon content of the sample. The estimated quantity of ${ }^{13} \mathrm{C}$ present at natural abundance (calculated on the basis of isotope ratios in control plants) was subtracted from this amount to arrive at the quantity of excess ${ }^{13} \mathrm{C}$ incorporated in the plant tissue due to the incubation procedure.

Estimation of biomass production. Estimations of below-ground production were made by combining the data on ${ }^{13} \mathrm{C}$ allocation to above-ground and belowground tissues with estimations of the net biomass increment of the shoots at the time of each of the field experiments. At Day 0, i.e. 6 to $11 \mathrm{~d}$ before the incubation with ${ }^{13} \mathrm{C}$, the length $(S)$ of each standing shoot and the total length $(L)$ of the living green leaves of each shoot in the incubation plots were measured. On the same day three $25 \times 25 \mathrm{~cm}$ plots were harvested, and in these samples as well the length of each shoot and the total length of the living green leaves per shoot were determined. The material subsequently was dried. Several regression equations then were tested to find an appropriate relation between length $S$, length $L$ and the dry weight of a shoot. The best-fitting equation (determined with the method of least squares) was selected for estimation of the dry weight of the shoots in the incubation plots at Day 0 .

Four days after incubation the above-ground vegetation of the incubation plots was harvested, and the total dry weight of the shoots in each plot was determined. By subtracting the estimated biomass present at Day 0 from this measured dry weight, the net above-ground biomass production over the period from Day 0 to the harvest day (between 10 and 15 d) was obtained. This value was translated into net amounts of carbon fixed into the shoots, using data on carbon content of aboveground tissues. Subsequently, the net amounts of carbon fixed below-ground were estimated assuming that the measured ratio of ${ }^{13} \mathrm{C}$ allocation to shoots and to 
roots was equal to the ratio of net carbon fixation above-ground and below-ground over the period from Day 0 to the harvest day:

$$
\frac{{ }^{13} \mathrm{C}_{\mathrm{a}}}{{ }^{13} \mathrm{C}_{\mathrm{b}}}=\frac{\mathrm{NC}_{\mathrm{a}}}{\mathrm{NC}_{\mathrm{b}}}
$$

where ${ }^{13} \mathrm{C}_{\mathrm{a}(\mathrm{b})}$ is the amount of the heavy carbon isotope allocated to above-ground or below-ground tissues $4 \mathrm{~d}$ after incubation, and $\mathrm{NC}_{\mathrm{a}(\mathrm{b})}$ is the net amount of carbon fixed above-ground or below-ground. Values of $\mathrm{NC}_{b}$ found by solving the equation were transformed into net biomass production values using the measured levels of carbon in the root/rhizome tissues.

\section{RESULTS}

\section{Seasonal variation in biomass and carbon content}

The below-ground biomass of Spartina anglica was always conspicuously higher than the above-ground biomass in spring and summer (Fig. 1). Both types of biomass changed significantly during the observation period (ANOVA, $p<0.001$ ). The above-ground biomass started at near-zero levels at the beginning of the growing season in May, and increased until August. $S$. anglica is a perennial plant, and substantial belowground biomass is present throughout the year (e.g Groenendijk \& Vink-Lievaart 1987). Analyses of root/ rhizome biomass in soil cores indicated an increase from May until August, followed by a decrease in September. More than $85 \%$ of the biomass was found in the upper $20 \mathrm{~cm}$ of the sediment (results not shown).

The carbon contents of the above-ground and below-ground tissues at the beginning of the growing

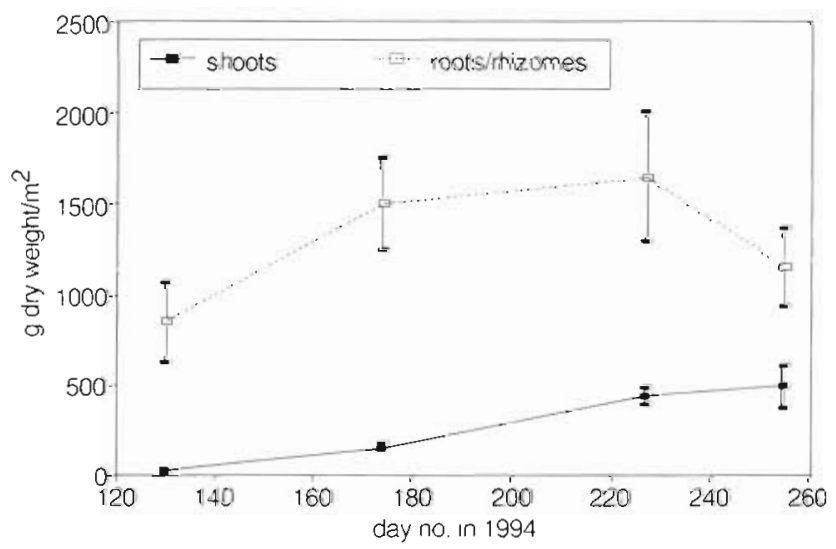

Fig. 1. Spartina anglıca. Seasonal course of above-ground and below-ground biomass. Means $\pm \mathrm{SD}(\mathrm{n}=3$, shoot samples; $\mathrm{n}=$ 4. root/rhizome samples). Samples were collected on May 10 (day no. 130), June 23 (day no. 174). August 15 (day no. 227) and September 12 (day no. 255)

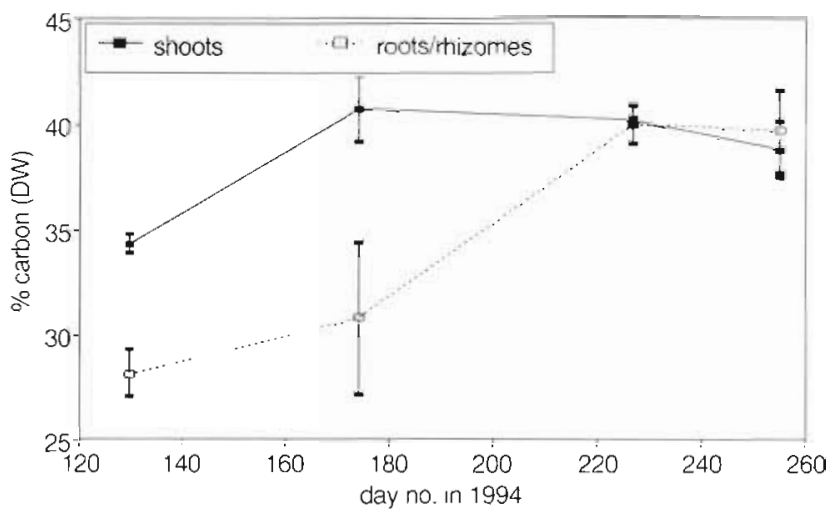

Fig. 2. Spartina anglica. Seasonal changes in carbon content (percentage of dry weight, DW) of above-ground and belowground bromass. Means $\pm \mathrm{SD}$ ( $\mathrm{n}=3$, shoot samples; $\mathrm{n}=4$, root/rhizome samples). Samples were collected on May 10 (day no. 130). June 23 (day no. 174), August 15 (day no. 227) and September 12 (day no. 255)

season were low, particularly in the roots/rhizomes ( $28 \%$ of dry wt), but levels increased to ca $40 \%$ in the second part of the growing season (Fig. 2).

\section{Carbon allocation}

Taking the intrinsic carbon dioxide absorption by IRGA and its limited sensitivity for ${ }^{13} \mathrm{CO}_{2}$ into consideration, it could be calculated that, during incubations, between 35 and $66 \%$ of the added ${ }^{13} \mathrm{C}$ was taken up by the plants (results not shown). Part of the fixed carbon is consumed in respiration and another part is fixed in the biomass, thus contributing to net primary production. Table 1 gives the $\delta^{13} \mathrm{C}$ values of shoots and roots/rhizomes $4 \mathrm{~d}$ after incubation, and the calculated absolute amounts of ${ }^{13} \mathrm{C}$ allocated to these tissues. The $\delta^{1: 3} \mathrm{C}$ values of the leaves varied between 15.17 and $381.5 \%$. These values indicate strong enrichment with the heavy carbon isotope. For comparison, we measured mean $8^{13} \mathrm{C}$ values of $-15.9,-12.9,-13.3$ and $-12.5 \%$ in blank (non-exposed) leaf samples collected in May, June, August and September, respectively. $\delta^{13} \mathrm{C}$ levels of the below-ground tissues varied between -0.1 and $71.1 \%$. These values also indicate clear enrichment of the tissues with the heavy carbon isotope (blank root/rhizome samples gave average values of $-14.2,-13.0,-12.8$ and $-12.5 \%$ in May, June, August and September, respectively). However, pairwise comparisons of below-ground samples with matching above-ground samples show that the roots/rhizomes were always much less enriched than the shoots. In line with these results, calculation of the absolute amounts of ${ }^{3} \mathrm{C}$ allocated to shoots and to roots/rhizomes shows that the shoots consistently 
Table 1. Spartina anglica. Stable carbon isotope ratios and ${ }^{13} \mathrm{C}$ contents of shoots (s) and roots/rhizomes ( $r$ ) in plots after experimental field exposure to ${ }^{13} \mathrm{CO}_{2}$. The ratio given is the ratio of ${ }^{13} \mathrm{C}$ allocated to corresponding shoots and roots/rhizomes Mean ratios sharing a common letter indicate that the respective groups are not significantly different (ANOVA on data in

'Ratio $s / r$ ' column, followed by post hoc contrasts; $\mathrm{p}<0.05$ )

\begin{tabular}{|c|c|c|c|c|c|c|}
\hline Period & Plot & $\begin{array}{l}\text { Plant } \\
\text { part }\end{array}$ & $\delta^{13} \mathrm{C}$ & $\begin{array}{l}\text { Enrichment } \\
\text { in }{ }^{13} \mathrm{C}(\mathrm{mg})\end{array}$ & $\begin{array}{c}\text { Ratio } \\
s / r\end{array}$ & $\begin{array}{c}\text { Mean } \\
\text { ratio }\end{array}$ \\
\hline \multirow[t]{6}{*}{ May } & 1 & s & 3310 & 0.593 & \multirow{2}{*}{2.50} & \multirow{6}{*}{$2.43^{a}$} \\
\hline & 1 & r & -0.1 & 0.237 & & \\
\hline & 2 & s & 381.5 & 0.538 & \multirow{2}{*}{2.50} & \\
\hline & 2 & r & 7.4 & 0.215 & & \\
\hline & 3 & s & 320.9 & 1.053 & \multirow{2}{*}{2.28} & \\
\hline & 3 & I & 9.4 & 0.461 & & \\
\hline \multirow[t]{6}{*}{ Jun/Jul } & 1 & $\mathrm{~s}$ & 273.1 & 6.479 & \multirow{2}{*}{4.31} & \multirow{6}{*}{$3.07^{\mathrm{a}}$} \\
\hline & 1 & r & 32.1 & 1.502 & & \\
\hline & 2 & $s$ & 360.5 & 4.300 & \multirow{2}{*}{2.89} & \\
\hline & 2 & I & 53.6 & 1.485 & & \\
\hline & 3 & $s$ & 240.9 & 4.312 & \multirow{2}{*}{2.01} & \\
\hline & 3 & $r$ & 71.1 & 2.145 & & \\
\hline \multirow[t]{6}{*}{ Aug } & 1 & s & 110.3 & 1.426 & \multirow{2}{*}{4.40} & \multirow{6}{*}{$6.19^{b}$} \\
\hline & 1 & r & 1.7 & 0.324 & & \\
\hline & 2 & s & 52.1 & 1.587 & \multirow{2}{*}{8.35} & \\
\hline & 2 & $r$ & -8.2 & 0.190 & & \\
\hline & 3 & s & 74.2 & 2.180 & \multirow{2}{*}{5.81} & \\
\hline & 3 & r & 1.1 & 0.375 & & \\
\hline \multirow[t]{6}{*}{ Sep } & 1 & s & 28.8 & 0.358 & \multirow{2}{*}{1.31} & \multirow{6}{*}{$1.60^{\mathrm{c}}$} \\
\hline & 1 & $r$ & -1.4 & 0.273 & & \\
\hline & 2 & s & 74.5 & 1.296 & \multirow{2}{*}{1.79} & \\
\hline & 2 & $\mathrm{r}$ & 13.3 & 0.726 & & \\
\hline & 3 & s & 15.2 & 0.328 & \multirow{2}{*}{1.71} & \\
\hline & 3 & r & -4.0 & 0.192 & & \\
\hline
\end{tabular}

obtained the largest share of the heavy isotope. The ratio of carbon allocated to the shoots and to the roots/rhizomes (Table 1) was between 2.28 and 2.50 in May, increased in June, and reached its highest values (4.40 to 8.35) in August. The ratio decreased again in September to values below 2 .

\section{Export of ${ }^{13} \mathrm{C}$}

The quantity of ${ }^{13} \mathrm{C}$ exported via the rhizome system to plant parts outside the incubation plots was assessed by carbon isotope analysis of biomass samples collected at specific distances away from the centre of the incubation plots. All observations made at similar distances were pooled into 'distance groups'. Hence, at the end of the period of field work, 12 observations on below-ground samples were available for each specific distance; for above-ground material only 6 observations were available for each specific distance, because in 2 of the 4 experiments no above-ground material was collected outside the incubation plots. Export of
Table 2. Translocation of ${ }^{13} \mathrm{C}$ out of Spartina anglica incubation plots, expressed as amounts of ${ }^{13} \mathrm{C}$ relative to the amounts remaining within the incubation plots (set at 100). The values indicate the translocation of ${ }^{13} \mathrm{C}$ to shoots and roots/rhizomes in increasingly wider concentric areas around the incubation plots (circular areas with a radius of $7 \mathrm{~cm}$ ). Results are based on the compiled observations after the 4 successive incubation experiments. For further detalls, see text

\begin{tabular}{|lcc|}
\hline Concentric area & Shoots & Roots/rhizomes \\
\hline $0-7 \mathrm{~cm}$ (incubation plots) & 100 & 100 \\
$7-14 \mathrm{~cm}$ & 3.51 & 12 \\
$14-21 \mathrm{~cm}$ & 1 & 1.05 \\
$21-28 \mathrm{~cm}$ & 2.59 & 2.36 \\
$28-35 \mathrm{~cm}$ & 2.61 & 0.82 \\
\hline
\end{tabular}

${ }^{13} \mathrm{C}$ from the incubation plot was considered to have taken place if the $\delta^{13} \mathrm{C}$ value of the material collected outside the plot was enriched by more than $0.5 \%$ as compared to average blank values (of shoots or roots/rhizomes) measured during the experiment in question. The proportion of enriched samples in each distance group was considered indicative of the proportion of the total corresponding concentric area receiving excess ${ }^{13} \mathrm{C}$. Assuming that the concentric area receiving excess ${ }^{13} \mathrm{C}$ was enriched to the mean level of enriched samples of the distance group in question, a rough estimation of the quantity of ${ }^{13} \mathrm{C}$ exported from the incubation area to the surrounding concentric areas can be made. Enrichment of shoots and roots/rhizomes sampled outside the incubation area was repeatedly found, indicating that export of the heavy carbon isotope via the rhizome system out of the incubation area did occur. The first concentric ring directly outside the incubation area was the major sink of this exported carbon (Table 2), but transport extended at least to the outer concentric ring that was sampled: in this outer ring, 1 out of the $12 \mathrm{root} / \mathrm{rhizome}$ samples and 1 out of the 6 shoot samples were enriched in ${ }^{13} \mathrm{C}$.

\section{Estimation of biomass production}

The relation between shoot dry weight $(Y)$, length of the shoot $(S)$ and total length of its leaves $(L)$ was best described when the natural logarithm of $Y, S$ and $L$ was taken. The formula used to estimate initial shoot weights (at Day 0) in the incubation plots was of the following general form:

$$
\ln Y=a+b \ln S+c \ln L+d(\ln S)^{2}+e(\ln L)^{2} .
$$

Comparison of the estimated above-ground biomass and the observed biomass at the end of the experiments showed that during the first 2 observation peri- 
Table 3. Spartina anglica. Estimations of biomass production (dry wt) of shoots (s) and of roots/rhizomes ( $r$ ) during the observation periods ( 10 to 12 d) in May and June/July

\begin{tabular}{|c|c|c|c|c|c|c|c|}
\hline \multirow{3}{*}{$\begin{array}{l}\text { Period } \\
\text { May }\end{array}$} & \multirow{3}{*}{$\begin{array}{c}\text { Plot } \\
\text { no. } \\
1\end{array}$} & \multirow{2}{*}{\multicolumn{2}{|c|}{$\begin{array}{l}\text { Shoot biomass } \\
\text { Initial }^{\text {a Final }} \\
\left(\mathrm{mg} \mathrm{plot}^{-1}\right)\end{array}$}} & \multicolumn{4}{|c|}{ Biomass production } \\
\hline & & & & \multicolumn{2}{|c|}{$\underset{\left(\mathrm{mg} \mathrm{plot}^{-1}\right)}{\mathrm{s}}$} & \multicolumn{2}{|c|}{${ }^{s}\left(g^{-2}\right)^{r}$} \\
\hline & & 560 & 1021 & 461 & 225 & 300 & 14 \\
\hline & 2 & & & & & & 6 \\
\hline & 3 & 867 & 1572 & 705 & 377 & 45.8 & 24 \\
\hline & 1 & & & & & & \\
\hline \multirow[t]{2}{*}{ July } & 2 & & & & & & \\
\hline & 3 & 3656 & 5750 & 2094 & 1379 & 136.1 & 89. \\
\hline
\end{tabular}

${ }^{a}$ Regression equations used to determine initial shoot biomass in the incubation plots:

May. $\ln Y=-6.318+1446 \ln S+0.374 \ln L$ $-0.105(\ln S)^{2}+0.029(\ln L)^{2}$ $\left(\mathrm{n}=99, \mathrm{R}^{2}=0.96\right)$

June: $\ln Y=1.823+0.252 \ln S+0.285 \ln L$ $+0.162(\ln S)^{2}+0.0377(\ln L)^{2}$ ( $\mathrm{n}=136, \mathrm{R}^{2}=0.89$ )

where $Y=$ dry weight of shoot $(\mathrm{mg}) ; \mathrm{S}=$ length of shoot $(\mathrm{cm}) ; L=$ total length of leaves per shoot $(\mathrm{cm})$

ods (in May and in June/July), biomass increased in the plots (Table 3). During the last 2 periods later in the growing season (August and September), however, most plots apparently experienced a 5 to $15 \%$ decrease (results not shown). As only living material was taken into account for biomass estimations, these decreases indicate that later in the growing season the amount of leaf material that died outweighed newly formed leaf material. As carbon fixation in biomass (and hence, growth) did occur in August and September (Table 1), the data obtained in these periods obviously have no relation with actual biomass production, and thus are excluded from further consideration.

The estimates of root/rhizome production during the 10 to $12 \mathrm{~d}$ observation periods in May and in June/July (Table 3) are based on the biomass increments of the shoots, the measured ratios of carbon allocated to shoots and roots/rhizomes, and the carbon contents of the tissues. Averaged over 3 replicate plots and expressed per $\mathrm{m}^{2}$, estimated production of shoots and roots/rhizomes was 29.7 and $15.2 \mathrm{~g} \mathrm{dry} \mathrm{wt} \mathrm{m}^{-2}$, respectively, in the penod May 10 to May 20. These values are 113.4 and $55.3 \mathrm{~g}$ dry $w t \mathrm{~m}^{-2}$, respectively, for the period June 23 to July 5

\section{DISCUSSION}

The present study shows that, as far as the study of carbon flow in salt marsh ecosystems is concerned, sta- ble carbon isotopes can be applied not only for the analysis of food web structure le.g. Peterson \& Howarth 1987, Sullivan \& Moncreiff 1990) or diagenesis of organic matter (Fogel et al. 1989, Benner et al. 1991), but also to in situ studies of carbon allocation to different compartments of the vegetation and to estimations of below-ground biomass production. ${ }^{14} \mathrm{C}$ has been used for the study of carbon allocation in earlier years (Hull et al. 1976), but the use of radioactive compounds in field studies is no longer an option.

The use of ${ }^{13} \mathrm{C}$ in allocation and growth studies has several advantages. First, the method gives an instantaneous picture of the partitioning of carbon, without having to rely on biomass measurements carried out at relatively wide time intervals. This makes it possible to detect rapid changes in allocation patterns, and consequently allows these patterns to be better associated with other dynamic phenomena in the salt marsh ecosystem. Second, using ${ }^{13} \mathrm{C}$ as a tracer, the pattern of carbon allocation can be measured in the shoot and root biomass of the same plant; this will result in much more accurate data on the pattern of carbon partitioning between shoot and root systems than can be derived from data on differences in average biomass between samples. The underlying assumptions for the validity of the results obtained with ${ }^{13} \mathrm{C}$ are the same as in comparable ${ }^{14} \mathrm{C}$ pulse-labelling experiments that have been carried out in laboratory studies (Warembourg \& Kummerow 1991). It is assumed, firstly, that the brief exposure (ca $1 \mathrm{~h}$ ) to ${ }^{13} \mathrm{C}$-enriched carbon dioxide and its subsequent assimilation provides a representative picture of the pattern of carbon flow in the plant over a time scale of days, and secondly, that the ${ }^{13} \mathrm{C}$-tracer is not selectively treated in different biochemical pathways, leading to misleading data on the overall allocation pattern. With respect to the first assumption, we have no a priori reason to doubt its validity, but we acknowledge the fact that possible variations in carbon allocation in relation to e.g the phase of the spring/neap tidal cycle or in relation to the light regime have not been specifically addressed in the present study. This point needs attention in future studies. With respect to the second assumption, it is relevant that other studies have shown that isotopic fractionation may occur during biosynthesis of plant compounds (Lajtha \& Marshall 1994). In the case of Spartina alterniflora it has been found that the lignin component is 4 to $7 \%$ more depleted in ${ }^{13} \mathrm{C}$ than the polysaccharides that make up the bulk of the plant tissues (Benner et al. 1987, 1991). The level of different biochemical fractions in Spartina shoot and root systems may vary seasonally, but not necessarily in a parallel fashion (Lytle \& Hull 1980a, b, Livingstone \& Patriquin 1981, Gallagher et al. 1984). Varying levels of synthesis and storage of specific compounds in 
shoots and roots thus are a potential cause of differences between the carbon isotope signatures of these organs, while at the same time, carbon allocation to above-ground and below-ground tissues may not be quantitatively different. However, in our study the largest difference in $\delta^{13} \mathrm{C}$ values between shoots and roots/rhizomes of control (non-exposed) plants was $1.7 \%$ (in May). This indicates that variable isotopic fractionation associated with the synthesis of different tissue components has only a limited impact on the overall isotope signature of the plant material. We therefore expect that the influence of isotopic fractionation on the overall pattern of carbon allocation as found in our experiments is small.

The isotope signatures of plant samples collected outside the incubation area indicate that carbon compounds can be transported along the rhizome system over distances of at least $25 \mathrm{~cm}$ (Table 2). Translocation of nitrogen-containing compounds was recently reported in Spartina patens (Hester et al. 1994). Obviously, source-sink relations exist between connected ramets of Spartina spp., as has been found in other clonal plant species (see e.g. review by Marshall 1990). For practical reasons it was only feasible to collect subsamples of the biomass surrounding the incubation area. The calculated values of ${ }^{13} \mathrm{C}$ export out of the incubation plots therefore must be considered as approximations, particularly in the outer concentric areas where enrichment of samples was infrequently found. It is clear, however, that export of carbon out of the ${ }^{13} \mathrm{C}$-exposed area is limited compared to what remains within the incubation plot. Equally important, the relative amounts of ${ }^{13} \mathrm{C}$ estimated to be present in the shoots and in the roots/rhizomes outside the incubation area, as compared to their quantities within this area, are of the same order of magnitude 10 and $16 \%$, respectively). The export of ${ }^{13} \mathrm{C}$ out of the incubation area therefore does not affect the validity of the pattern of carbon allocation to shoots and roots/rhizomes as observed in the ${ }^{13} \mathrm{C}$-exposed areas.

The data on enrichment of above-ground and belowground biomass show that there is a considerable temporal variation in the proportion of carbon that is allocated to above-ground and below-ground organs, with average ratios increasing from 2.43 in May to 6.19 in August, followed by a sudden drop to 1.6 in September (Table 1). The latter decrease may be related to the storage of underground carbohydrate reserves late in the growing season, as has been observed in Spartina alterniflora (Lytle \& Hull 1980a, b, Livingstone \& Patriquin 1981). Apart from the seasonal variation, a second conspicuous outcome of the allocation experiments is that the investigated $S$. anglica population consistently invested more carbon in above-ground than in below-ground plant parts. This finding strongly suggests that on an annual basis, above-ground biomass production outweighs below-ground biomass production. It is interesting to note that the data on the seasonal course of shoot and root biomass as such (Fig. 1) do not lead to this conclusion. Above-ground biomass increased (between May 10 and September 12) by only $467 \mathrm{~g}$ dry wt $\mathrm{m}^{-2}$, whereas root/rhizome biomass increased by a larger amount, viz. $801 \mathrm{~g}$ dry wt $\mathrm{m}^{-2}$ (between May 10 and August 15). The actual biomass production, however, may be very different from measured biomass increments, if senescence and death of certain plant tissues occur simultaneously with growth of other parts. These processes certainly co-occur in Spartina shoots, particularly later in the growing season, when both development of leaves and flowering stems and senescence of older leaves can be observed.

The data on ${ }^{13} \mathrm{C}$ allocation can be used to estimate the root/rhizome production over short-term periods (less than $2 \mathrm{wk}_{\text {; }}$ Table 3 ). A condition for application of the calculation procedure is that growth of the shoots over the period in question be measured. The assumption involved here is that the ratio of ${ }^{13} \mathrm{C}$ allocation to above-ground and below-ground tissues (measured $4 \mathrm{~d}$ after a short-term incubation) is similar to the ratio of the carbon increment (growth) of these tissues over a more extended observation period (10 to $15 \mathrm{~d}$ in this study). A clear increase of above-ground biomass was established during the early growth phase in May and June/July only. We assumed that this increase approximated actual biomass production, as senescence and leaf death during the early growth phase probably is marginal. No net increase in above-ground biomass, however, was found later on in the season, most probably due to the increased importance of leaf death at more advanced stages of shoot development. To determine shoot production later in the growing season (and to be able to arrive at estimations of below-ground production over short term periods) thus probably would require frequent determination of both leaf growth and leaf death.

The absence of reliable data on growth in the second part of the growing season impedes an accurate estimation of net annual biomass production, but we can use the production data obtained in May and June/July for a rough approximation. Assuming that the relatively low production in the period May 10 to 20 is representative for the first and last month of the growing season (May and September; Groenendijk 1984), and the value obtained in the period June 23 to July 5 is representative for the months in between, the annual above-ground and below-ground biomass production would be 1130 and $556 \mathrm{~g} \mathrm{~m}^{-2}$, respectively. In Fig. 3, a compilation of data from the literature is presented, which shows that in the majority of studies on 


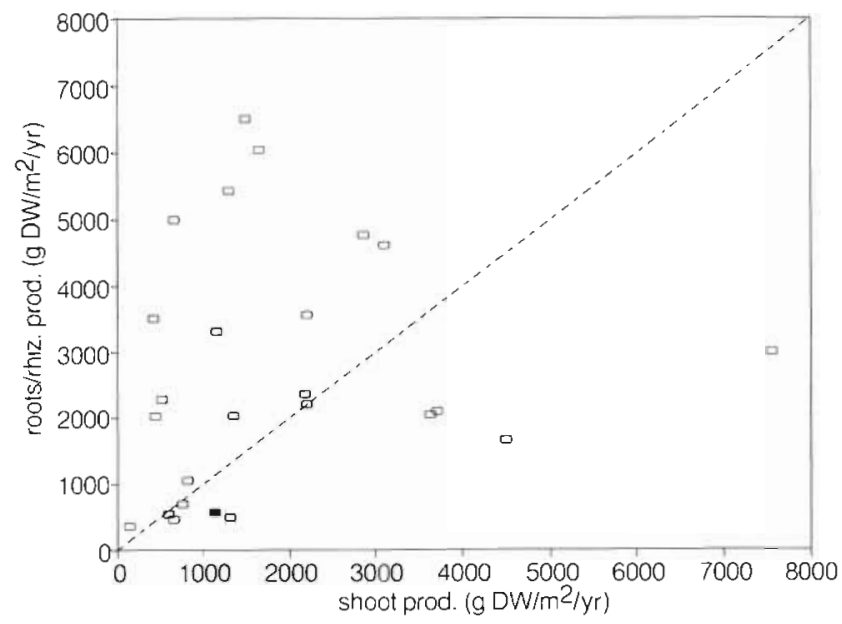

Fig. 3. Compilation of published values of above- and belowground biomass production of Spartina spp. obtained with harvest techniques. Values [dry weights, DW] derived from: Stroud \& Cooper (1968), Stroud (1976) (both cited in Schubauer \& Hopkinson (1984) I; Valiela et al. (1976), Gallagher \& Plumley (1979), Smith et al. (1979), Gallagher et al (1980), Livingstone \& Patriquin (1981), Groenendijk (1984), Roman \& Daiber (1984), Schubauer \& Hopkinson (1984), Dame \& Kenny (1986), Ellison et al. (1986), Hackney \& de la Cruz (1986), Jackson et al. (1986), Groenendijk \& VinkLievaart (1987), da Cunha Lana et al. (1991). Filled symbol: value obtained in this study

Spartina spp below-ground biomass production prevails over above-ground production. Most of these studies pertain to $S$. alterniflora. In the only 2 relevant studies on $S$. anglica, root/rhizome production was conspicuously higher than shoot production (Groenendijk \& Vink-Lievaart 1987; cf. Groenendijk 1984), or nearly equal to shoot production (Jackson et al. 1986). In the studies included in Fig 3, below-ground productivity estimates were derived from changes in total macro-organic material. The reliability of this type of productivity measurement may be debatable; it nonetheless seems unlikely that the frequently inferred conclusion of higher biomass production belowground than above-ground is entirely unfounded. Apparently, the ratio of shoot to root production of natural Spartina vegetation is highly variable, ranging from a clear dominance of shoot production (as is suggested by our data) to the completely opposite situation with root/rhizome production amply exceeding shoot production.

The variation in the relative importance of aerial and below-ground production may imply considerable differences in the functioning of Spartina-dominated marsh systems with respect to element cycling. In marsh vegetations with a proportionally high aerial production, aerobic decomposition of standing dead culms and attached leaves by associated microbial assemblages (Buth \& Voesenek 1987, Newell et al. 1989 ) is expected to play a prominent role in the mineralization of organic matter; in vegetation with a predomination of below-ground biomass production, anaerobic mineralization processes which are intimately linked to sulphur and nitrogen cycles (Howarth 1993) can be expected to be more important. To what extent root exudates complicate this scheme is an intriguing question. Soluble root-derived organic compounds and mucous secretions that enter the rhizosphere may constitute up to $5 \%$ of the photosynthates produced by the plants (Lambers 1987). Even higher percentages have been calculated by including the organic enrichment of the rhizosphere with particulate cell debris coinciding with cell death of root tissues (Helal \& Sauerbeck 1986, Lynch \& Whipps 1990). Rates and patterns of sulfate reduction in salt marshes probably change in response to root exudation activity (Howarth \& Hobbie 1982, Hines et al. 1989). The latter authors found a 5 -fold increase in sulfate reduction when $S$. alterniflora began growing above-ground, but a 4 -fold decrease upon plant flowering, which suggested that root exudation rate was influenced by shoot development. As yet, rates of sulfate reduction have not been coupled to in situ root growth, nor to actual rates of root exudation. Future detailed studies of the root/rhizome system will be indispensable to elucidate the complex interactions between plants and biogeochemical processes in salt marsh sediments.

Acknowledgements. The authors are indebted to Drs J. B. M. Middelburg and Th. E. Cappenberg for critically readjng the manuscript. This is publication no. 2070 of the Netherlands Institute of Ecology, Yerseke.

\section{LITERATURE CITED}

Adam P (1990) Saltmarsh ecology. Cambridge University Press, Cambridge

Bakker JP, de Leeuw J, Dijkema KS, Leendertse PC, Rozema $J$ (1993). Salt marshes along the coast of The Netherlands. Hydrobiologia 265:73-95

Benner R, Fogel ML, Sprague EK (1991). Diagenesis of belowground biomass of Spartina alterniflora in salt-marsh sediments. Limnol Oceanogr 36(7):1358-1374

Benner R, Fogel ML, Sprague, EK, Hodson RE (1987). Depletion of ${ }^{13} \mathrm{C}$ in lignin and its implications for stable carbon isotope studies. Nature 329:708-710

Boutton TW (1991) Stable carbon isotope ratios of natural materials: I. Sample preparation and mass spectrometric analysis. In: Coleman DC, Fry B (eds) Carbon isotope technıques. Academic Press, San Diego, p 155-172

Buth GJC, Voesenek LACJ (1987) Decomposition of standing and fallen litter of halophytes in a Dutch salt marsh. In: Huiskes AHL, Blom CWP.M Rozema J (eds) Vegetation between land and sea. Dr W Junk Publ, Dordrecht, $p$ $43-59$

da Cunha Lana P, Gurss C. Trevisan Disaro S (1991) Seasonal variation of biomass and production dynamics for aboveand belowground components of a Spartina alterniflora 
marsh in the euhaline sector of Paranaguá Bay (SE Brasil) (1991). Estuar coast Shelf Sci 32:231-241

Dame RF, Kenny PD (1986) Variability of Spartina alterniflora primary production in the euhaline North lnlet estuary. Mar Ecol Prog Ser 32:71-80

Ellison AM, Bertness MD, Miller T (1986) Seasonal patterns in the belowground biomass of Spartina alterniflora (Gramineae) across a tidal gradient. Am J Bot 73(11): $1548-1554$

Fogel ML, Sprague EK, Gize AP, Frey RW (1989) Diagenesis of organic matter in Georgia salt marshes. Estuar coast Shelf Sci 2:211-230

Gallagher JL. Plumley FG (1979) Underground biomass profiles and productivity in Atlantic coastal marshes. Am J Bot 66:156-161

Gallagher JL, Reimold R, Linthurst R, Pfeiffer W (1980) Aerial production, mortality, and mineral accumulation-export dynamics in Spartina alterniflora and Juncus roemerianus plant stands in a Georgia salt marsh. Ecology 61:303-312

Gallagher JL, Wolf PL, Pfeiffer WJ (1984) Rhizome and root growth rates and cycles in protein and carbohydrate concentrations in Georgia Spartina alterniflora Loisel. plants. Am J Bot 71(2):16j 169

Groenendijk AM (1984) Primary production of four dominant salt-marsh anglosperms in the SW Netherlands. Vegetatio $57: 143-152$

Groenendijk AM, Vink-Lievaart MA (1987) Biomass and production on a Dutch salt marsh: emphasis on the belowground component. Vegetatio 70:21-27

Hackney CT, de la Cruz AA (1986) Belowground productivity of roots and rhizomes in a giant cordgrass marsh. Estuaries $9(2): 112-116$

Helal HM, Sauerbeck D (1986) Effect of plant roots on carbon metabolism of soil microbial biomass. Z Pllanzenernähr Bodenkd 149:181-188

Hester MW, McKee KL, Burdick DM, Koch MS, Flynn KM, Patterson S, Mendelssohn IA (1994) Clonal integration in Spartina patens across a nitrogen and salinity gradient. Can J Bot 72:767-770

Hines ME, Knollmeyer SL, TugeI JB (1989) Sulfate reduction and other sedimentary biogeochemistry in a northem New England salt marsh. Limnol Oceanogr 34(3):578-590

Howarth RW (1993) Microbial processes in salt-marsh sediments. In: Edgcumbe Ford $T$ (ed) Aquatic microbiology. Blackwell, Oxford, p 239-261

Howarth RW, Hobbie JE (1982) The regulation of decomposition and heterotrophic activity in salt marsh soils: a review. In: Kennedy VS (ed) Estuarine comparisons. Academic Press, New York, p 183-207

Hull RJ, Sullivan DM, Lytle RW (1976) Photosynthate distribution in natural stands of salt water cordgrass. Agron J 68: 969-972

Jackson D, Long SP, Mason CF (1986) Net primary producthon, decomposition and export of Spartina anglica on a Suffolk salt-marsh. J Ecol 74:647-662

King GM (1988) Patterns of sulfate reduction and the sulfur cycle in a South Carolina salt marsh. Limnol Oceanogr 33(3):376-390

Lajtha K, Marshall JD (1994) Sources of variation in the stable isotopic composition of plants. In: Lajtha K, Michener RH (eds) Stable isotopes in ecology and environmental science. Blackwell, London, p 1-21

Lambers $\mathrm{H}$ (1987) Growth, respiration, exudation and symbiotjc associations: the fate of carbon translocated to the roots. In: Gregory PJ, Lake JV, Rose DA (eds) Root development and function-effects of the physical environment. Cambridgo Unuversity Press, Cambridge, p 125-145
Lindau CW, DeLaune RD (1991) Dinitrogen and nitrous oxide emissions and entrapment in Spartina alternuflora salt marsh soils following addition of $\mathrm{N}-15$ labelled ammonium and nitrate. Estuar coast Shelf Sci 32:161-172

Livingstone DC, Patriquin DG (1981) Belowground growth of Spartina alterniflora Loisel.: habit, functional biomass and non-structural carbohydrates. Estuar coast Shelf Sci 12 : $579-587$

Long SP, Mason CF (1983) Saltmarsh ecology. Blackıe, Glasgow

Lynch JM, Whipps JM (1990) Substrate flow in the rhizosphere. Plant Soil 129:1-10

Lytle RW, Hull RJ (1980a) Photoassimilate distribution in Spartina alterniflora Lolsel. I1. Autumn and winter storage and spring regrowth. Agron J 72:938-942

Lytle RW, Hull RJ (1980b) Annual carbohydrate variation in culms and rhizomes of smooth cordgrass (Spartina alterniflora Loisel.). Agron J 72:942-946

Marshall C (1990) Source-sink relations of interconnected ramets. In: van Groenendaal J, de Kroon $\mathrm{H}$ (eds) Clonal growth in plants. SPB Academic Publ, The Hague, p 23-43

McCree KJ (1974) Equations for the rate of dark respiration of white clover and grain sorghum, as function of dry weight, photosynthetic rate and temperature. Crop Sci $14: 509-514$

Mendelssohn IA, McKee KL, Patrick WH Jr (1981) Oxygen deficiency in Spartina alterniflora roots: metabolic adaptation to anoxia. Science 214:439-441

Mordacc L, Mousseau M, Deleens E (1986) A ${ }^{13} \mathrm{C}$ method of estimation of carbon allocation to roots in a young chestnut coppice. Plant Cell Environ 9:735-739

Morris JT, Houghton RA, Botkin DP (1984) Theoretical limits of belowground production by Spartina alterniflora: an analysis through modelling. Ecol Model 26:155 175

Newell SY, Fallon RD, Miller JD (1989) Decomposition and microbial dynamics for standing, naturally positioned leaves of the salt-marsh grass Spartina alterniflora. Mar Biol 101:471-481

Peterson BJ, Howarth RW (1987) Sulfur, carbon and nitrogen isotopes used to trace organic matter flow in the saltmarsh estuaries of Sapelo Island, Georgia. Limnol Oceanogr 32(6): 1195-1213

Reddy KR, Patrick WH, Lindau CW (1989) Nitrification-denitrification at the plant root-sediment interface in wetlands Lumnol Oceanogr 34(6):1004-1013

Roman CT, Daiber FC (1984) Aboveground and belowground primary production dynamics of two Delaware Bay tidal marshes. Bull Torrey Bot Club 11:34-41

Ryle GJA, Cobby JM. Powell CE (1976) Synthetic and maintenance respiratory losses of ${ }^{14} \mathrm{CO}_{2}$ in uniculm barley and maize. Annls Bot 40:571-586

Schubauer JP, Hopkinson CS (1984) Above- and belowground emergent macrophyte production and turnover in a coastal marsh ecosystem, Georgia. Limnol Oceanogr 29(5):1052-1065

Smith KK, Good RE, Good NF (1979) Production dynamics for above and belowground components of a New Jersey Spartina alterniflora tidal marsh. Estuar coast Shelf Sci 9:189-201

Stroud LM (1976) Net primary production of belowground material and carbohydrate patterns in two height forms of Spartina alterniflora in two North Carolina marshes. PhD thesis, North Carolina State Univ, Raleigh

Stroud LM, Cooper AW (1968) Color infra-red aerial photographic interpretation and net primary productivity of a regularly flooded North Carolina marsh. North Carolina Water Resources Research Institute Report 14 
Sullivan MJ, Moncreiff CA (1990) Edaphic algae are an important component of salt marsh food-webs: evidence from multiple stable isotope analyses. Mar Ecol Prog Ser 62:149-159

Svejcar TJ, Boutton TW, Trent JD (1990) Assessment of carbon allocation with stable carbon isotope labeling. Agron J 82:18-21

This article was submitted to the editor
Valiela I, Teal JM, Persson NY (1976) Production and dynamics of experimentally enriched salt marsh vegetation: belowground biomass. Limnol Oceanogr 21:245-252

Warembourg FR, Kummerow J (1991) Photosynthesis/translocation studies in terrestrial ecosystems. In: Coleman C, Fry B (eds) Carbon isotope techniques. Academic Press, San Diego, p 11-37

Manuscript first received: March 27, 1995 Revised version accepted: July 13, 1995 